\title{
Growth of rainbow trout (oncorhynchus mykiss) in the conditions of Tashkent province, Uzbekistan
}

\author{
SH Sulaymonov ${ }^{1, *}, G$ Abdullaev ${ }^{2}$, and $S$ Saidumarov $^{2}$ \\ ${ }^{1}$ Navoi State Pedagogical Institute, Navoi, Uzbekistan \\ ${ }^{2}$ Tashkent State Agrarian University, University str., 2, Tashkent province, 100140 Uzbekistan
}

\begin{abstract}
Rainbow trout is a new fish farming object for Uzbekistan, the adaptability of which (first of all, growth) to local conditions should be carefully studied. We analyzed the growth of rainbow trout in the conditions of flowing pools and cages in the foothill zone of Tashkent province of Uzbekistan. From March to October, the water temperature in the Khojikent reservoir varied from 4.9 to $13.1{ }^{\circ} \mathrm{C}$, the amount of dissolved oxygen was 8.4 to $11.5 \mathrm{mg} / 1$, and the $\mathrm{pH}$ was 7.40 to 7.67 . In the flowing basin, the temperature was $15-18{ }^{\circ} \mathrm{C}, \mathrm{pH} 7.2-7.5$, the amount of dissolved oxygen $6.1-11.2 \mathrm{mg} / \mathrm{l}$. The conditions of the foothill zones of Uzbekistan in terms of water quality are favorable for the development of trout breeding. During the season, fish in cages increased from $250 \mathrm{~g}$ to $623 \mathrm{~g}$, in pools from $25 \mathrm{~g}$ to $390 \mathrm{~g}$ on average. The waste was $1.7 \%$. The actual fish productivity of the basin is $39 \mathrm{~kg} / \mathrm{m}^{3}$, the cage is $30 \mathrm{~kg} / \mathrm{m}^{3}$ and the feed coefficient in the basin is 1.2 , in the cages -1.09 .
\end{abstract}

\section{Introduction}

For the development of integrated water use and rational use of water resources, technologies are needed in which aquaculture will be an additional function in the reservoir, and the list of cultivated objects will consist not only of warm-water fish [1-4, 7-10]. These requirements are met by new approaches for the republic of intensive cultivation of rainbow trout (Oncorhynchus mykiss) in floating fish cages and flowing pools [5, 6], which are currently being developed commercially only in "Golden Fish Group" LLC in Tashkent province. Rainbow trout is a new fish farming object for Uzbekistan, the adaptability of which (first of all, growth) to local conditions should be carefully studied. Within the framework of the local research project KH-A-KH-2018-196 "Technology of growing marketable trout in flowing basins in the conditions of Tashkent province", this work was carried out in order to characterize the growth of rainbow trout in different types of conditions in the foothill zone of Tashkent province.

\footnotetext{
*Corresponding author: o.a.sulaymonov@yandex.com
} 


\section{Materials and methods}

The work was carried out in the cage complex of the fish farm "Golden Fish Group" LLC, installed in the Khodjikent reservoir (this is a reservoir with very cold water compared to other reservoirs of the republic), as well as in the complex of flowing basins of the same fish farm in the vicinity of Urtasaray in the Urtachirchik district of Tashkent province in the foothill zone near the Karasu canal, where it was possible to regulate and maintain the water temperature in the basin of $15-18{ }^{\circ} \mathrm{C}$ by mixing the water supply from the irrigation canal and from the well (and this is the optimal conditions for rainbow trout). In both cases, part of one generation of rainbow trout obtained from the "Golden Fish Group" hatchery was planted simultaneously in the indicated types of hatchery systems.

The pool measuring $6 \times 1 \times 1.2 \mathrm{~m}$ was stocked with 600 pieces of juvenile rainbow trout weighing 20 - 31 (on average 25) g. During stocking, the water temperature was $9.2{ }^{\circ} \mathrm{C}$ (March 12). Sandors were installed in the pool so that the water depth was $50 \mathrm{~cm}$. Since May, the water level has been raised to the planned level of $1 \mathrm{~m}$.

The Khodjikent reservoir is located downstream of the dam of the Charvak reservoir, from which water is discharged from the lower part of the dam, therefore the water in the reservoir is cold all year round. This creates the specificity of the hydrochemical state of water in the reservoir. The cage fish farm is installed along the right bank of the Khodjikent reservoir, the cages are located virtually in a straight line (Fig. 1). The fish farm grows trout in the conditions of industrial fish farming, the actual fish productivity of trout is $30-40$ $\mathrm{kg} / \mathrm{m}^{3}[1,2]$.

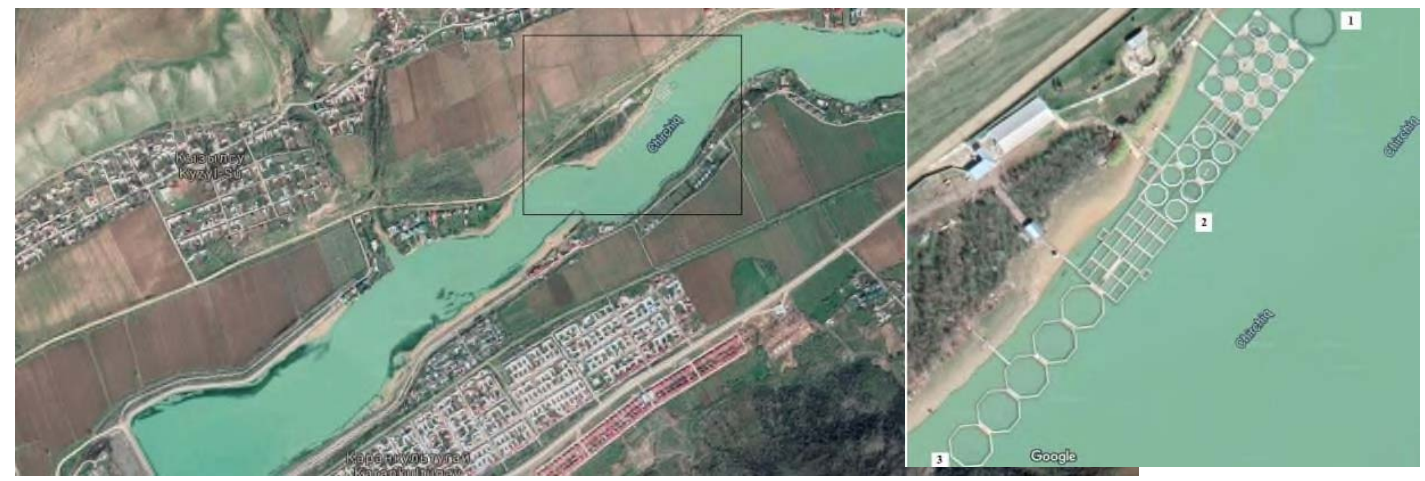

Fig. 1. Khodjikent reservoir in Tashkent province, Uzbekistan.

In the Khodjikent reservoir, 3000 specimens of rainbow trout with an average individual body weight of $239.6 \mathrm{~g}$ were planted in an experimental cage with a volume of $75 \mathrm{~m}^{3}$ on March 24-25. The total biomass of fish was $720 \mathrm{~kg}$. In the cage fish farm at 3 stations (1the highest point of the fish farm, 2- the experimental cage, and 3- the lowest point of the fish farm) during the growing season (February - October) 2019, the amount of dissolved oxygen $(\mathrm{mg} / \mathrm{l}$ with an accuracy of 0.1$)$ and temperature $\left({ }^{\circ} \mathrm{C}\right.$, with an accuracy of 0.1$)$ was measured using a HANNAHI 9147 thermooximeter, $\mathrm{pH}$ (with an accuracy of 0.01 ) using a portable $\mathrm{pH}$ meter $\mathrm{pHscan} 30 \mathrm{~S}$. In the pool, water quality indicators were determined in the middle of the reservoir [1-4].

In the cultivation of rainbow trout, the forage of the Coppens Company was used for the cultivation of commercial rainbow trout (which are currently freely sold in the republic). The diet was calculated weekly according to the manufacturer's recommendations, taking into account the biomass of fish and the temperature of the water in the reservoir, which were established during control fishing. The daily dose of feed was introduced in small portions: during the day, passing by the pool 5-8 times, the fish farmer 
scooped up the feed with a plastic scoop and scattered it widely over the pool. This feeding technique is more effective than 2-3 meals a day.

Control catches were carried out weekly, determining the average weight of fish in the sample, then - the total biomass of fish in the experimental cage. Based on these data, in accordance with the feed passport (from the manufacturer), the optimal diet for the next week was calculated. The diet took into account the expected growth of the fish. In accordance with the size of the fish, the size of the granules was selected, also based on the recommendations of the manufacturer.

\section{Results and discussion}

\subsection{Fishery water quality}

In the basin economy in Urtasaray, the salinity of water throughout the year was $500-742$ $\mathrm{mg} / \mathrm{l}$, which is fresh water. The hydrogen index $(\mathrm{pH})$ varied from 7.2 to 7.5. The amount of dissolved oxygen only in July and August decreased to $6.1 \mathrm{mg} / \mathrm{l}$, the rest of the time during the study period it varied from 8.6 to $11.2 \mathrm{mg} / \mathrm{l}$, the indicated oxygen regime corresponds well to the requirements of the species. Nevertheless, in June-August, water spray was used in the pool as additional aeration.

The dynamics of water temperature is given by months in Table 1. It can be seen that, according to this parameter, the water quality was favorable for trout breeding.

Table 1. Dynamics of water temperature in the pool with marketable trout.

\begin{tabular}{|c|c|}
\hline Months & Water temperature, ${ }^{\mathbf{0}} \mathbf{C}$ \\
\hline April & 10.4 \\
\hline May & 16.4 \\
\hline June & 17.1 \\
\hline July & 17.3 \\
\hline August & 17.2 \\
\hline September & 16.8 \\
\hline October & 15.9 \\
\hline
\end{tabular}

2.

The results on the water temperature in the reservoir near the cages are shown in Table

Table 2. Water temperature in the studied biological stations in the cage fish farm.

\begin{tabular}{|c|c|c|c|c|c|c|}
\hline \multirow{3}{*}{ Station } & \multicolumn{6}{|c|}{ Water temperature, ${ }^{\mathbf{0}} \mathbf{C}$ (according to analysis dates) } \\
\cline { 2 - 7 } & $\begin{array}{c}\text { February } \\
\mathbf{1}\end{array}$ & March 1 & April 1 & May 16 & July 16 & $\begin{array}{c}\text { Octobe } \\
\text { r 20 }\end{array}$ \\
\hline 1 & 4.9 & 5.1 & 7.1 & 11.1 & 13.0 & 10.1 \\
\hline 2 & 5.0 & 5.2 & 8.2 & 11.4 & 13.3 & 10.3 \\
\hline 3 & 5.0 & 5.2 & 6.9 & 11.7 & 13.1 & 10.1 \\
\hline
\end{tabular}

Only in mid-May the water warmed up to a level at which the growth of trout was noticeable - above $11{ }^{\circ} \mathrm{C}$, and from October it began to decrease to $10^{\circ} \mathrm{C}$. The Khojikent reservoir is deep. We analyzed whether there is a difference in water temperature at different depths since the beginning of April (Table 3). The temperature on the water surface and at depths of $1 \mathrm{~m}$ and $2 \mathrm{~m}$ differed quite noticeably by $0.3-1.2{ }^{\circ} \mathrm{C}$. The difference was especially large in the middle and in the lower part of the fish farm. 
Table 3. Water temperature $\left({ }^{\circ} \mathrm{C}\right)$ at different depths in the cage fish farm, Khodjikent reservoir.

\begin{tabular}{|c|c|c|c|}
\hline Stations & Sampling depth, m & April 1 & May 16 \\
\hline \multirow{3}{*}{1} & 0 & 7.1 & 11.1 \\
\cline { 2 - 4 } & 1 & 6.8 & 11.0 \\
\cline { 2 - 4 } & 2 & 6.8 & 10.8 \\
\hline \multirow{3}{*}{2} & 0 & 8.2 & 11.4 \\
\cline { 2 - 4 } & 1 & 7.0 & 11.1 \\
\cline { 2 - 4 } & 2 & 6.8 & 10.9 \\
\cline { 2 - 4 } & 0 & 6.9 & 11.7 \\
\cline { 2 - 4 } & 1 & 6.8 & 11.1 \\
\hline \multirow{3}{*}{3} & 2 & 6.8 & 10.9 \\
\hline
\end{tabular}

Rainbow trout is an oxyphilic fish. The maximum permissible concentration (MPC) for trout is the lowest value of $6 \mathrm{mg} / \mathrm{l}$. The data on the value of dissolved oxygen are given in Table 4. At depths of $1 \mathrm{~m}$ and $2 \mathrm{~m}$, the amount of dissolved oxygen was higher than at the water surface.

Table 4. The amount of oxygen dissolved in water $(\mathrm{mg} / \mathrm{l})$ at different depths in a cage fish farm, Khodjikent reservoir.

\begin{tabular}{|c|c|c|c|c|c|}
\hline Stations & $\begin{array}{c}\text { Sampling } \\
\text { depth, m }\end{array}$ & April 1 & May 16 & July 16 & October 26 \\
\hline \multirow{3}{*}{1} & 0 & 11.5 & 9.8 & 8.8 & 10.9 \\
\cline { 2 - 6 } & 1 & 11.3 & 10.1 & 9.1 & 11.2 \\
\cline { 2 - 6 } & 2 & 11.6 & 10.3 & 9.3 & 11.3 \\
\hline \multirow{3}{*}{2} & 0 & 10.2 & 9.4 & 8.4 & 10.6 \\
\cline { 2 - 6 } & 1 & 11.0 & 9.6 & 8.5 & 10.8 \\
\hline \multirow{3}{*}{3} & 2 & 11.2 & 9.9 & 8.7 & 10.9 \\
\cline { 2 - 6 } & 0 & 11.2 & 9.5 & 8.2 & 10.3 \\
\cline { 2 - 6 } & 1 & 11.1 & 9.8 & 8.5 & 10.5 \\
\hline
\end{tabular}

The hydrogen potential $(\mathrm{pH})$ varied from 7.4 to 7.67 throughout the year. For trout, $\mathrm{pH}$ values slightly above 7 are considered favorable; the water in the Khodjikent reservoir is close to very favorable for rainbow trout.

The amount of dissolved ammonium ion $\left(\mathrm{NH}_{4}{ }^{+}\right)$is one of the most important indicators of water quality for intensive aquaculture. The maximum permissible concentration for trout breeding by the amount of dissolved ammonium ion is $1.0 \mathrm{mg} / \mathrm{l}$. During the year, the indicator varied from 0.00 to 0.08 . The water in the Khodjikent reservoir in the winterspring period is very clean and does not contain ammonium ions at all. This is a favorable factor for trout farming.

Throughout the year, the total hardness of water was $2.0 \mathrm{mg}$-eq/1 (at maximum permissible concentrations of 1.5-7.0), mineralization was $110 \mathrm{mg} / \mathrm{l}$ (MPC 1000-1500), hydrocarbons were $17.5 \mathrm{mg}-\mathrm{eq} / \mathrm{l}$ (MPC 60-120), chloride concentration was $0.709 \mathrm{mg} / \mathrm{l}$ (MPC 25-40), color - $540 \mathrm{~nm}$.

Thus, the water of the Khodjikent reservoir is favorable for the development of trout breeding.

In November, 590 individuals were caught from the basin, their mortality was $1.7 \%$ (for comparison, the standard of waste in pond fish farming is more than $15 \%$ ). At the same time, a piece-by-piece withdrawal was noted only in May.

In the cage fish farm, the last control fish catch was carried out on November 7, 2019. All fish from the cage were caught, counted and transplanted into other cages of the 'Golden Fish' fish farm, based on their production needs. During the period of rearing, no fish was found, 3,000 individuals were caught and the yield was $100 \%$. 


\subsection{Growth of marketable trout}

The growth of marketable trout from April to October in the basin is shown in Table 5 . Note that the data are given for the last week of the month. The experiment was completed in October, and the pool was completely fished in early November. A generation of commercial rainbow trout has been successfully reared in the flowing basin. According to the results of the fishing, the fish sizes varied within the range of $290-424 \mathrm{~g}$. Note that the commercial rainbow trout weighing $250 \mathrm{~g}$. Thus, the technology tested in the experience of 2020 makes it possible to confidently grow commercial rainbow trout in the foothill zone of the republic. Even the minimum weighed amount was in the experiment $290 \mathrm{~g}$. The total biomass of fish was $230 \mathrm{~kg}$, which means that the experiment achieved an actual fish productivity of $39 \mathrm{~kg} / \mathrm{m}^{3}$ and the target was $30 \mathrm{~kg} / \mathrm{m}^{3}$.

Table 5. Growth of individual body weight of marketable trout in the experiment.

\begin{tabular}{|c|c|c|c|}
\hline \multirow{2}{*}{ Months } & \multicolumn{3}{|c|}{ Body mass, $\mathbf{g}$} \\
\cline { 2 - 4 } & Min & Max & Mean \\
\hline April & 29.2 & 61.1 & 39.4 \\
\hline May & 44.6 & 64.1 & 55.4 \\
\hline June & 59.4 & 69.4 & 64.9 \\
\hline July & 95 & 140 & 103.4 \\
\hline August & 161 & 201 & 173.4 \\
\hline September & 198 & 290 & 242.2 \\
\hline October & 290 & 424 & 390 \\
\hline
\end{tabular}

Trout biomass growth taking into account mortality is shown in Fig. 2.

\section{Fish biomass, $\mathrm{kg}$}

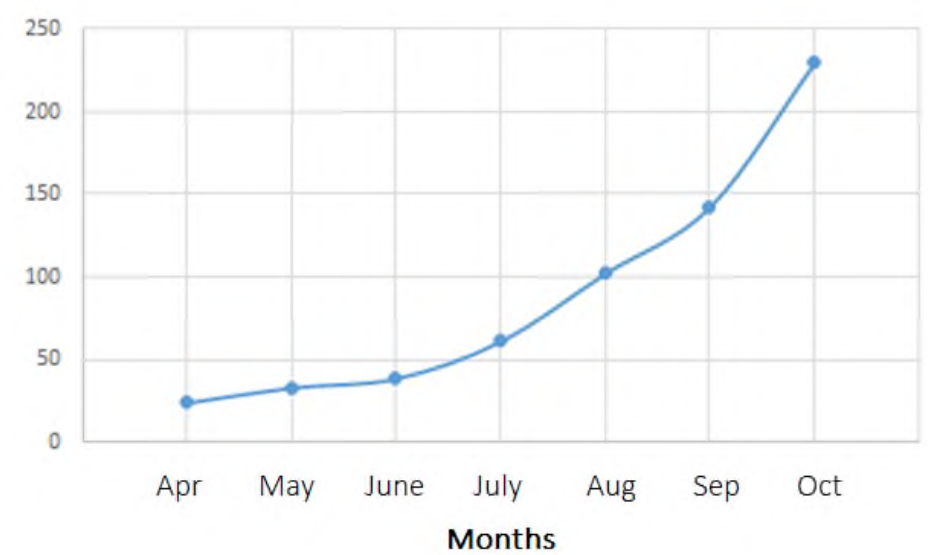

Fig. 2. Growth of biomass of commercial rainbow trout in the basin, Tashkent province.

The growth of rainbow trout in the cage fish farm is shown in Table 6 and in Fig. 3. The final average individual body weight was $623.3 \mathrm{~g}$. The increase in the individual fish body weight averaged $371.8 \mathrm{~g}$ over 7 months. 
Table 6. Growth rate of an experienced rainbow trout in a fish hatchery.

\begin{tabular}{|c|c|}
\hline Months (2019) & $\begin{array}{c}\text { Average individual body weight of } \\
\text { trout, } \mathbf{g}\end{array}$ \\
\hline April & 251.2 \\
\hline May & 301.1 \\
\hline June & 375.0 \\
\hline July & 421.0 \\
\hline August & 474.2 \\
\hline September & 529 \\
\hline October & 623 \\
\hline
\end{tabular}

According to the growth of the total biomass of fish in the experimental cage, the dynamics looks as follows. $720 \mathrm{~kg}$ rainbow trout were planted in April. The final fish biomass was $1870 \mathrm{~kg}$. The total increase in rainbow trout biomass was $1,150 \mathrm{~kg}$. Thus, the actual fish productivity was $25 \mathrm{~kg} / \mathrm{m}^{3}$.

\section{Average body weight, $\mathrm{g}$}

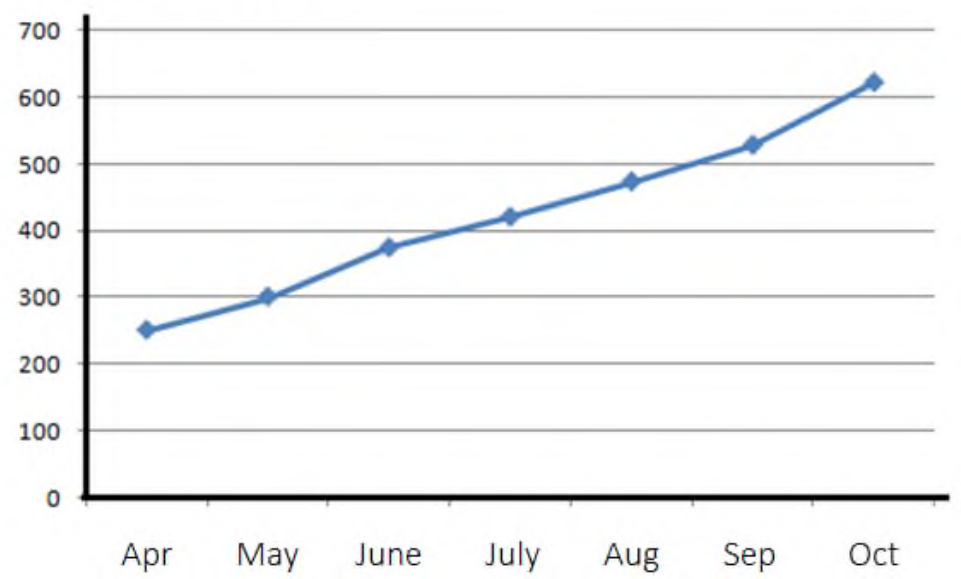

Fig. 3. Growth rate of an experienced rainbow trout in a hatchery, Tashkent province.

\subsection{Feed ratio}

The most important indicator of the entire technology and the level of culture of the fish farm is the feed ratio. In the basin economy, the fodder coefficient in dif-ferent months varied from 1.19 to 1.3 , while from the middle of summer the coefficient dropped sharply and did not exceed 1.2. We associate this with the growth of fish, an increase in their biomass. As a result, all the feed was consumed by the fish, and the loss of feed pellets was reduced. In total, $254.4 \mathrm{~kg}$ of feed was introduced into the pool for the entire growing season. The increase in the total biomass of fish for the season was $215 \mathrm{~kg}$. Thus, the feed ratio was 1.18 .

A total of $1200 \mathrm{~kg}$ of Coppens feed for commercial rainbow trout was added to the pilot cage. Thus, the feed ratio was 1.09 . This is a very high indicator characterizing the high level of fish farm technology and high quality feed. 


\section{Discussion and conclusions}

Fish production in Uzbekistan in the period 2009 - 2020 is almost entirely (99\%) based on pond polyculture of carp fish in earthen ponds (while up to $90 \%$ of total production falls on silver carp (Hypophthalmichthys molitrix); total fish production in the republic has increased dramatically in the specified period from 6-9 thousand tons/year to about 100 thousand tons/year The fish productivity of earthen ponds is $20-25$ quintals/ha (in terms of $0.1-0.17 \mathrm{~kg} / \mathrm{m} 3$ ), pond farms are located in the warm water fish breeding, in the conditions of the so-called VII zone of fish breeding, in which 151 days or more per year in a year have an average daily water temperature above $15^{\circ} \mathrm{C}$, and the annual sum of average daily temperatures of days with temperatures above $15{ }^{\circ} \mathrm{C}$ is $2,561-4,122{ }^{\circ} \mathrm{C}$ [1], since cultivated fish grow when the water warms up above $18-20{ }^{\circ} \mathrm{C}$, the optimal for rapid growth is the season when the water warms up above $24^{\circ} \mathrm{C}$. In fact, the foothill and mountainous parts of the republic are not used and cannot be used by carp pond polyculture. Also, pond polyculture is not a technology for complex water use, because for biotechnological reasons, ponds are targeted water users (water is poured into the pond for the entire growing season, and at the end of the season, most of it is released into the collector-drainage system, sometimes back to the irrigation system). In the conditions of an objective tense state in the availability of available water resources for water users in our arid country, for their rational use, fish production technologies with a much higher productivity are required.

However, they are practically not used for the needs of the fishery. Even in lowland reservoirs, fish productivity is $5-10 \mathrm{~kg} / \mathrm{ha}$, with the predominance of low-value roach. At the same time, these reservoirs are an essential resource for fish farming. However, there are no aquaculture technologies in the republic that would allow the use of lenticular reservoirs, including the irrigation system. The most promising system is floating fish cages. For cold-water areas, rainbow trout can be a promising cultivation object. The Khodjikent reservoir, in comparison with other reservoirs in the foothill and even mountainous zones of the republic, is distinguished by very cold water throughout the year, since water comes from the lower layers of the Charvak reservoir. The water temperature did not exceed $13{ }^{\circ} \mathrm{C}$ even in summer. In other water bodies of the foothill and mountain zones, the temperature regime is more favorable for trout breeding. But, even in such conditions, the technology of industrial cage farming of rainbow trout, provided that the dependence of feeding on water temperature and fish size is taken into account, shows high rates and provides a high profitability of raising marketable fish. A well-prepared biological substantiation of trout cultivation can be recommended throughout the foothill and mountainous zones of the republic.

Our data show that even in the very cold (within Uzbekistan) Khodjikent reservoir, the water is favorable for trout, although the period of trout growth is rather limited. This means that all other reservoirs in the foothill zone are excellent for trout breeding. Such territories in the republic occupy more than $20 \%$, but more than $60 \%$ of the population living on them. Such territories are still poorly developed by fish farming, since the technology used in Uzbekistan - pond polyculture of carp fish - was developed for warmwater fish [2-4]; in these areas, the water is not warmed up to ensure the technologically advantageous growth of cyprinids.

In deep places of reservoirs and lakes, as well as large rivers with slow-flowing water, fish cages with a depth of 3-4 m (or more) can be used, the water quality at such depths is almost the same, but this will significantly increase fish productivity per unit area of water bodies. This is an effective method for more rational use of the republic's water resources.

In the foothill regions, the slope of the land is significant, which makes it possible to create flowing basins for cold water aquaculture, while water can move in the basins due to 
gravity. Thus, the basin system of trout breeding is promising near rivers, canals, and other water bodies. Since the complete water exchange in the basins is strictly recommended for no more than 1 hour, the basins can be considered as non-target water users; water simply flows through the basins and returns back to the surface runoff.

Thus, both fish cages and flowing basins for trout are technologies for integrated water use (moreover, as an additional function in reservoirs) in the country's water resources in the foothill zone that have not been used to date.

In almost all foothill regions of the republic, rainbow trout shows a high growth rate of marketable fish, which makes it possible to obtain valuable products in a short time within the terms recommended for trout breeding in the world experience.

According to the fish farm "Golden Fish Group", the cost of feed averaged 15,000 $\mathrm{UZS} / \mathrm{kg}$ in 2019. Thus, the cost of fodder in the cultivation of commercial trout amounted to $16,300 \mathrm{UZS} / \mathrm{kg}$. In intensive aquaculture, it is assumed that feed costs account for $70 \%$ of the cost of fish. The calculation shows that the cost of rainbow trout in our experience was about 23,200 UZS $/ \mathrm{kg}$. The selling price of trout from the Golden Fish Group fish farm is $30,000 \mathrm{UZS} / \mathrm{kg}$. Thus, the total profit will be $7000 \mathrm{UZS} / \mathrm{kg}$ and profitability was $30 \%$.

\section{References}

1. D. Abdunazarov, M. Yuldashov, U. Soatov, B. Kamilov, Trout Fish Industry, 164 (Lesson press, Tashkent, 2019)

2. B. Kamilov, R. Kurbanov, T. Salikhov, Fishery in Uzbekistan, 88 (Chinor ENK press, Tashkent, 2003)

3. B. Kamilov, M. Yuldashov, U. Soatov, I. Khalilov, Freshwater aquaculture of Uzbekistan, 156 (Gold-Print Nashr press, Tashkent, 2018)

4. M. Yuldashov, B. Kamilov, Bulletin of Karakalpak Branch of Uzbekistan Academy of Sciences, 4, 60-62 (2017)

5. R. M. Brown, G. D. Wiens, I. Salinas, Fish \& shellfish immunology, 86, 497-506 (2019)

6. G. Terova, S. Rimoldi, C. Ascione, E. Gini, C. Ceccotti, L. Gasco, Reviews in Fish Biology and Fisheries, 29(2), 465-486 (2019)

7. S. Kelson, M. Miller, T. Thompson, S. O'Rourke, S. Carlson, Canadian Journal of Fisheries and Aquatic Sciences, 76(11), 2080-2088 (2019)

8. Y. Altunoglu, S. Bilen, F. Ulu, G. Biswas, Fish \& shellfish immunology, 67, 103-109 (2017)

9. S. Yilmaz, S. Ergun, Fish \& shellfish immunology, 78, 140-157 (2018)

10. S. Hoseini, A. Mirghaed, Y. Iri, M. Ghelichpour, Aquaculture, 495, 766-772 (2018) 